\title{
Changes in lymphocyte phenotype and increased skin allograft survival after FTY720+FK506 therapy
} Modificação do fenótipo linfocitário e aumento da sobrevida do enxerto de pele após a terapia com FTY720 + FK506

Camila T. Lopes ${ }^{1}$

Léa B. L. Silval

Patricia M. Cury ${ }^{I}$

Emmanuel A. Burdmann ${ }^{l}$

Valquiria Bueno $^{2}$

\begin{abstract}
The development of new drugs to be associated with calcineurin inhibitors and promote additional immunosuppression with fewer side effects is the goal in transplantation. FTY720 is a new synthetic compound which presents immunomodulatory properties which are not fully understood. It has been reported that the main mechanism of action of FTY720 is to reduce the peripheral lymphocyte count by redirecting these cells toward secondary lymphoid organs. Skin allograft transplantation in a fully mismatched strain combination was used to investigate the potential of FTY720 alone or in combination with a calcineurin inhibitor - FK506 - in preventing rejection. The number and phenotype of immune system cells was also evaluated. FTY720 alone or in combination with FK506 provided significant skin allograft survival. FTY720+FK506 therapy was associated with decreases of total lymphocyte numbers in spleen and blood, and increases in apoptosis levels in splenocytes. In FTY720 isolated treatment, a significant decrease in the CD4 expression and significantly lower expressions of MHC II and ICAM-1 molecules were observed in spleen lymphocytes. Despite of allograft survival being the same in both FTY720 and FTY720+FK506 treated groups, the association of drugs was associated with the absence of macroscopic skin necrosis for a longer period than the other treatments (FTY720, FK506) and histology showed less cell infiltration. Our results suggest that a decrease of effector T cells due to elevated levels of apoptosis and impairment in the appearance of antigens were events associated with FTY720+FK506 administration. Rev. bras. hematol. hemoter. 2008;30(3):181-187.
\end{abstract}

Key words: Mice; skin allotransplantation; rejection; immunosuppression; flow cytometry.

\section{Introduction}

Improvement in immunosuppressive therapy is needed because rejection, infection, and drug toxicity remain to be the most common causes of morbidity and mortality in transplantation. Drugs with potential immunomodulatory/ immunosuppressive capabilities are associated with side effects or metabolism changes when administered for long periods. FTY720 is a synthetic compound analog to Isaria sinclaiiri extract that shows beneficial effects in experimental autoimmune diseases, tumor growth and metastasis, transplantation and ischemia-reperfusion injury. ${ }^{1-6}$ FTY720 binds to the same receptor of endogenous sphingosine-1 phosphate (S1P) and causes changes in lymphocyte trafficking by redirecting these cells to lymph nodes (LN) and Peyer's patches (PP) preventing therefore their migration to inflammatory sites. ${ }^{7}$

In the immune system, the major sources of S1P are mast cells, platelets and some types of mononuclear phagocytes. Sphingosine 1-phosphate (S1P) regulates diverse biological functions of many cell types, from proliferation and survival to migration and secretion. ${ }^{8-10}$

${ }^{I}$ Famerp - Faculdade de Medicina de São José do Rio Preto-SP.
${ }^{2}$ Unifesp - Universidade Federal de São Paulo - São Paulo-SP.

Correspondence: Valquiria Bueno

Rua Francisco Aquarone, 86

04026-020 - São Paulo-SP - Brasil

Tel.: (11) 8962-2943

valquiriabueno@hotmail.com; valquiria@nefro.epm.br 
S1P and FTY720 are recognized with high-affinity by a family of G-protein-coupled receptors. These receptors transduce signals following S1P/FTY720 binding by associating with one or more $\mathrm{G}$ proteins allowing a broad range of possible downstream targets. ${ }^{11,12}$

$\mathrm{S} 1 \mathrm{P}$ receptors $\left(\mathrm{S}_{\mathrm{P}} \mathrm{P}_{1-5}\right)$ expressed in T cells, B cells, and thymocytes at late developmental stages are $\mathrm{S}_{1} \mathrm{P}_{1}, \mathrm{~S}_{\mathrm{P}}$, and low levels of $\mathrm{S}_{1} \mathrm{P}_{3}$. S1P main activity seems to be the regulation of lymphocyte trafficking and distribution in lymphoid tissues through binding to $\mathrm{S}_{1} \mathrm{P}_{1}{ }^{8}$ The profile of $\mathrm{S} 1 \mathrm{P}-$-receptor expression is similar for $\mathrm{CD} 4^{+}$and $\mathrm{CD} 8^{+} \mathrm{T}$-cell subsets and for CD4+CD25+ regulatory T cells. ${ }^{13,14}$ In vitro concentrations of S1P between 10 and $100 \mathrm{nM}$ protected $\mathrm{T}$ cells from apoptosis by inhibition of caspases, and supported the effective function of both cytotoxic $\mathrm{T}$ lymphocytes and CD4+CD25+ regulatory T cells by increased generation of IL-10 and expression of cytotoxic T-lymphocyte antigen $4 .{ }^{15}$

FTY720 causes decrease at blood lymphocytes and slight increase of these cells in LN and PP after 6 to 24 hours of treatment. ${ }^{7,16}$ Lymphopenia was associated with increased skin allograft survival after FTY720 therapy even in mice (aly/aly) that not present secondary lymphoid organs such as lymph nodes and Peyers' patches. ${ }^{17}$ Morris et al. showed that FTY720 administered daily to wild C57BL/6 mice caused a sustained decrease in blood and spleen lymphocytes whereas the accumulation of these cells in lymph nodes was transient. ${ }^{18}$ FTY 720 treatment also causes accumulation of late-stage CD4 and CD8 single positive cells in the thymus, and intrathymic FITC labeling experiments confirmed that this accumulation is due to a block in thymic egress. ${ }^{19,20}$ Furthermore, FTY720 inhibits egress of activated $\mathrm{T}$ lymphocytes from LNs that are draining a site of immunization. ${ }^{21}$ Lymphopenia and the egress-blocking activities of FTY720 most likely explains many of its immunosuppressive effects, preventing effector cells from reaching transplanted tissue or sites that would normally be targeted by reactive cells. The prolonged exposure to FTY720 generates transient lymphocyte S1P1 downregulation and inactivation ${ }^{22,23}$ and in turn the egress of these cells from thymus and secondary lymphoid organs is blocked.

We recently showed synergy when FTY720 and Cyclosporine were associated with increase at skin allograft survival and without nephrotoxicity. ${ }^{24}$ However, it has been shown that some patients might not be submitted to CsA continuous administration due to toxicity and/or other side effects. In such cases, FK506 is a candidate for CsA substitution due its immunosuppressive potential. Therefore, it was our aim to investigate whether FTY720 in association with another calcineurin inhibitor (FK506) used in transplantation could prevent skin rejection in a fully mismatched strain combination and the possible changes caused in immune system.

\section{Material and Method}

Eight to 10 -week-old male BALB/c (H-2 ${ }^{\mathrm{d}}$, donor) and $\mathrm{C} 57 \mathrm{BL} / 6\left(\mathrm{H}-2^{\mathrm{b}}\right.$, recipient) mice were used (bred in a local colony) for the skin transplantation model. They received a standard mice diet and water ad libitum. Animals were cared for in accordance with the Principles of Laboratory Animal Care (NIH publication $\mathrm{N}^{\circ} 86-23$, revised 1985) and the regulations of the Brazilian Committee on Animal.

The drugs were administered daily for 21 days starting 3 days before skin allograft transplantation. FTY720 (Novartis, Basel, Switzerland, $1 \mathrm{mg} / \mathrm{kg} /$ day diluted in sterile distilled water) and/or FK506 (Fujisawa, Japan, 2 mg/kg/day diluted in sterile distilled water) were administered by gavage.

Donors and recipients were anesthetized with an intraperitoneal injection of Xylazine (Agribrands, Brazil) and Ketamine (Vetbrands, Brazil) diluted in $10 \mathrm{~mL}$ of sterile PBS (phosphate buffered solution-OXOID LTD Hampshire England). BALB/c mice had the tail skin removed and placed in cold saline. Tail skin was segmented in $1 \times 1 \mathrm{~cm}^{2}$ pieces and used to replace the previously removed back skin from C57BL/6 mouse. The skin graft was fixed with 4-0 sutures at each corner and animals were placed in individual cages for daily observation. Mice were observed daily to establish the rejection time $(<90 \%$ of skin necrosis) in a set of experiments and evaluated five days after transplantation for changes in immune system in a second set of experiments.

The peak of immune response is believed to occur five days after transplantation in allograft experimental models. ${ }^{25}$ Therefore five days after skin transplantation mice were anesthetized as described before and placed on a temperature controlled surgical table (Braile Biomédica, Brazil) with the purpose of opening the abdomen for blood collection and spleen harvesting. Blood samples were used for a smear test, whereas in spleen cell numbers and phenotype were determined.

Blood $(10 \mu \mathrm{L})$ collected from the vena cava was dropped toward one end of a slide and with a cover slip it was smeared back over the slide. A Panotico kit (Laborclin, Paraná, Brazil) was used for staining and leukocytes were identified and counted at microscopy.

For the examination of cell numbers in the spleen, single cell suspension was prepared by pressing it through a 400 $\mu \mathrm{m}$ sterile nylon mesh. Single cell suspension from spleen was submitted to 1 minute of distilled water with the aim of causing hemolysis. Cells from spleen were counted in a Neubauer chamber with the aid of a microscope.

\section{Flow cytometry}

$1 \times 10^{6}$ cells from spleen single cell suspension were incubated with rat anti-mouse (BD Biosciences Pharmingen) CD4 Gam-FITC, CD54 PE (ICAM-1), I-A b PE (MHC class II), or Annexin-V FITC (apoptosis) for surface marker staining. ${ }^{26}$ 
Cells were washed with FACS buffer (PBS/ $2 \%$ FCS) and evaluated in FACScalibur Flow Cytometer (BD Biosciences) using Cell Sorter software. The cell population was classified for size (forward scatter) and complexity (side scatter) with a gate set in the lymphocyte population. At least 10.000 cells were evaluated.

\section{Histology}

Skin sections were stained with hematoxylin and eosin (H\&E). Possible structure changes and cell infiltration were evaluated by a pathologist blinded to treatment arm. Infiltration score was defined as 0 (absence), 1 (mild), 2 (moderate) and 3 (intense).

\section{Statistical analysis}

Data are shown as mean \pm standard deviation. Kaplan-Meier analysis was used for skin allograft survival and comparisons among groups were performed by analysis of variance (ANOVA) followed by Tukey post-test for the other parameters evaluated, except for cell infiltration in transplanted skin where Mood Median Test was used. The level of statistical significance was defined as p-value $<0.05$.

\section{Results}

All treatments promoted significant skin allograft survival (Figure 1) when compared to non-treated mice. However, FTY720 alone or in association (FTY720

+ FK506) showed more efficacy in delaying skin allograft survival in a fully mismatched strain combination.

Table 1 shows that in all groups C57BL/6 recipient mice presented similar numbers of lymphocyte in the draining (axillary) lymph node. On the other hand, a significant decrease was observed in spleen and blood compartments when animals were treated with FTY720 + FK506. In blood, the same decreased number of lymphocytes was observed in FTY720 treated mice. FK506 single therapy was associated with an increase of lymphocyte numbers both in spleen and blood. CD4+ expression was lower in all treated groups when compared with Tx non-treated mice. However, this decrease was higher in the FTY720 Group.

FTY720 monotherapy caused a significant decrease at MHC II and ICAM-1 (activation markers) expression in splenocytes. For these same markers, FTY720+FK506 did not cause the same decrease as FTY720 but percentages where
Table 2. Changes in splenocytes phenotype after drugs treatment. Activation ( $\mathrm{MHC}$ II and ICAM-1) markers were decreased in FTY720 treated mice whereas apoptosis (Annexin V) markers were higher expressed in FTY720+FK506 treated recipients

\begin{tabular}{cccc}
\hline \multirow{2}{*}{ Groups } & \multicolumn{3}{c}{ Spleen lymphocytes } \\
\cline { 2 - 4 } & MHC I\% & ICAM-1\% & Annexin V\% \\
\hline TX-non treated & $46.7 \pm 12.0^{\mathrm{b}}$ & $92.6 \pm 0.7^{\mathrm{a}}$ & $23.8 \pm 3.8^{\mathrm{b}}$ \\
FTY720 & $37.0 \pm 1.6^{\mathrm{b}}$ & $81.0 \pm 4.7^{\mathrm{b}}$ & $44.4 \pm 5.1^{\mathrm{a}}$ \\
FK506 & $74.0 \pm 15.8^{\mathrm{a}}$ & $96.1 \pm 2.1^{\mathrm{a}}$ & $41.9 \pm 0.2^{\mathrm{ab}}$ \\
FTY720+FK506 & $56.1 \pm 12.3^{\mathrm{ab}}$ & $93.0 \pm 3.5^{\mathrm{a}}$ & $55.5 \pm 16.8^{\mathrm{a}}$ \\
p-value & $\mathrm{axb}_{0.001}$ & $\mathrm{axb}<0.0005$ & $\mathrm{axb}_{\mathrm{p}=0.002}$ \\
\hline
\end{tabular}

lower in the former when compared with FK506 treatment alone as shown in Table 2 .

Lymphocyte apoptosis was significantly higher in FTY720+FK506 Group in comparison with the other groups 
A



B

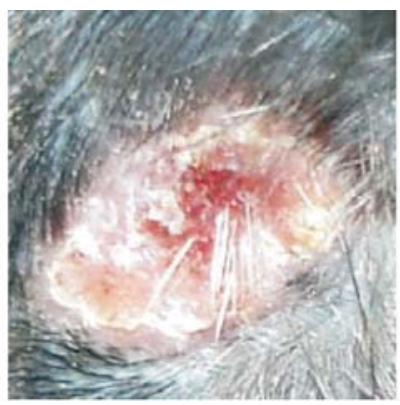

C

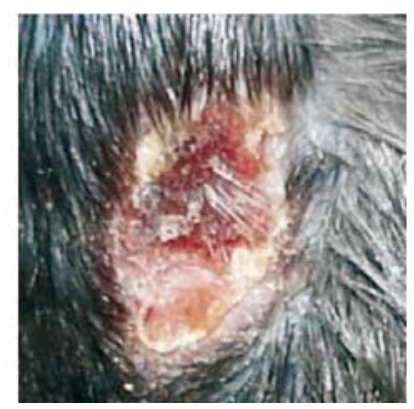

D

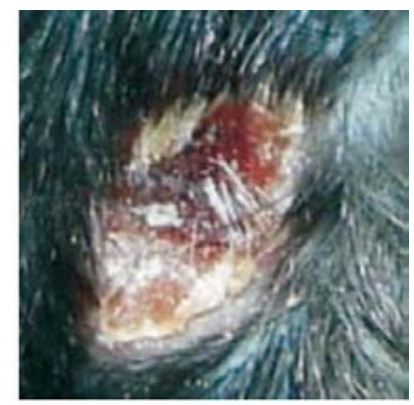

Figure 2.FTY720+FK506 treatment delays skin allograft rejection process in C57BL/6 mice transplanted with a fully mismatched strain combination (BALB/C). Evaluation of skin necrosis percentage. $A=10 \%($ Day +13$) ; B=20 \%($ Day +14$) ; C=50 \%(D a y+15) ; D=90 \%(D a y+16)$

A

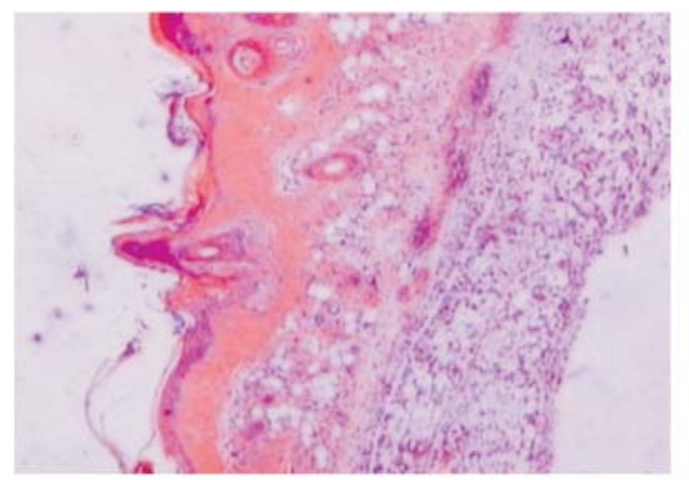

C

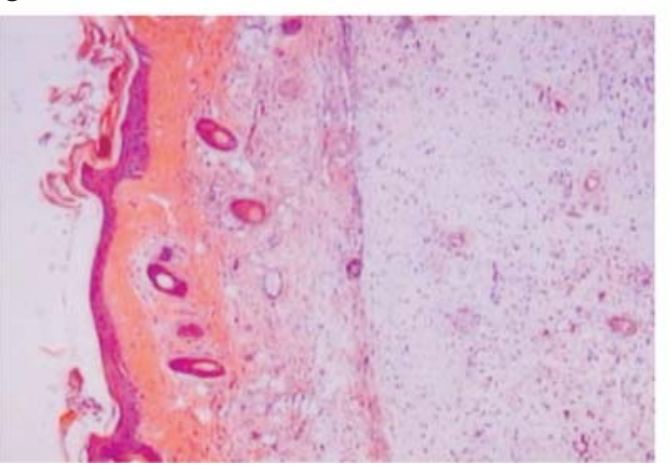

B

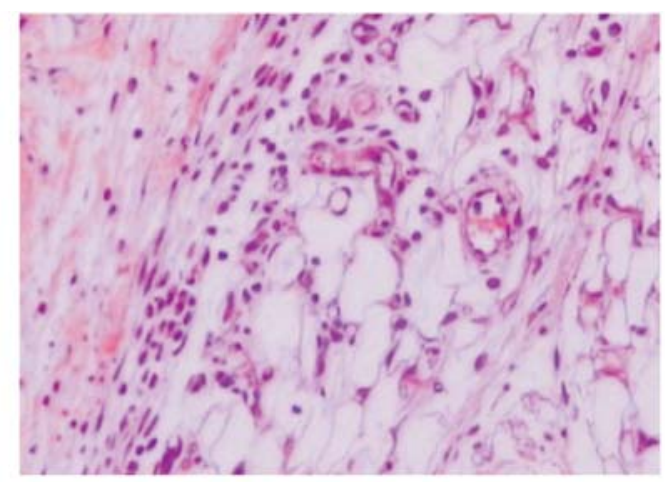

D

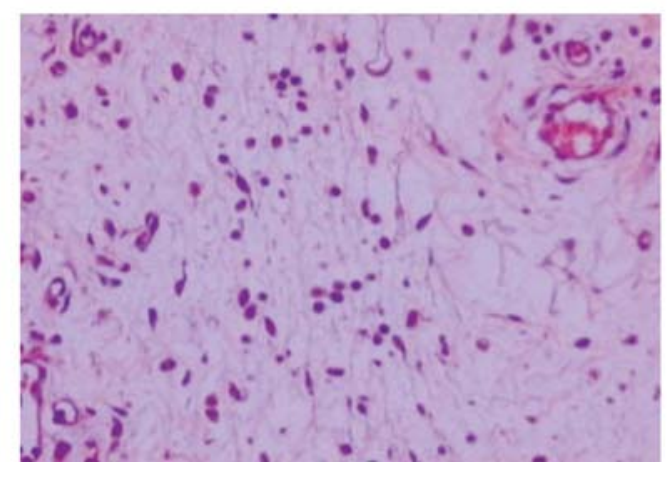

\begin{tabular}{lcclcc}
\hline Groups & Tx-non treated & FTY720 & FK506 & FTY720+FK506 & p-value \\
$\begin{array}{c}\text { Median of } \\
\text { cell infiltration }\end{array}$ & $2.0 \pm 0.5$ & $2.0 \pm 1.0$ & $2.0 \pm 1.5$ & $2.0 \pm 1.5$ & 0.40 \\
& $(n=5)$ & $(n=5)$ & $(n=5)$ & $(n=5)$ & \\
\hline
\end{tabular}

Figure 3. FTY720+FK506 treatment impaired but did not prevent cell infiltration in allogeneic transplanted skin. A.Tx-non treated (40x H\&E day +5 post transplant), B.detail of cell infiltration (200x H\&E); C. FTY720+FK506 (40x H\&E day +5 post transplant), D.detail of cell infiltration (200x H\&E). Median of cell infiltration in all groups compared by Mood Median test

while non-treated mice presented the lowest percentage of apoptosis (Table 2).

In Figure 2 it is possible to observe that in FTY720 +FK506 group the transplanted skin is highly preserved and the first tissue necrosis signs appear only 10 days after transplantation. However, this treatment was not capable to prevent cell infiltration and histology in FTY720+FK506 treated mice was only slightly different from Tx non-treated mice as observed five days after skin allograft transplantation (Figure 3). 


\section{Discussion}

Prevention of the rejection process without causing toxicity is a goal in transplantation. Therefore, new drugs have been developed with the aim that in association with lower doses of calcineurin inhibitors (CNIs) they would cause an additional immunosuppression with fewer side effects. We recently showed in mice that the administration for 21 days of FTY720 in association with FK506 protected kidney from histology changes and impaired the increase of glycemia caused by FK506 single therapy. ${ }^{27}$ However, there is no report of the immunosuppressive effect of FTY720+FK506 in delaying skin allograft survival in a fully mismatched strain combination. It has been shown that FTY720+CsA improve skin allograft survival in a fully mismatched strain combination without causing important changes in kidney function and structure. ${ }^{24}$ These results suggest that FTY720 can be associated to CNIs at least for a short period of time without causing enhanced kidney side effects.

In this study, both FTY720 alone or in association with FK506 promoted a significant increase at skin allograft survival in a fully mismatched strain combination (BALB/cC57BL/6). In absence of treatment, skin was rejected in 9 days whereas with the drug combination the maximum of allograft survival obtained was 16 days. FK506 single therapy caused a less important increase of skin allograft survival when compared with FTY720 and FTY720+FK506 treated groups.

In despite of the good results observed in experimental models using FTY720 its mechanism of action is not fully understood. In agreement with previous reports, ${ }^{19,28}$ our results showed that FTY720 causes decrease at blood lymphocytes. The same was observed when FTY720 was associated with FK506. Also in agreement with our data, Morris et al. showed that FTY720 administered daily to C57BL/6 mice caused a sustained decrease in blood and spleen lymphocytes whereas the accumulation of these cells in lymph nodes was transient. We found similar lymphocyte numbers in lymph nodes of all groups five days after skin allograft transplantation (nine days of FTY720 daily administration). Morris et al. observed that after ten days of FTY720 daily administration there was a return of T cells to the initial values in peripheral lymph nodes. ${ }^{18}$ FTY720+FK506 Group presented a decreased number of lymphocytes at spleen site suggesting that immunosuppression was based on lack of cells to cause rejection. It has been reported that FTY720 acts mostly in blood lymphocytes and has a major effect in $\mathrm{CD}^{+}$T cells. ${ }^{19,28}$ Our results showed that FTY720 alone or in combination with FK506 caused a more important decrease in splenic $\mathrm{CD} 4^{+} \mathrm{T}$ cells when compared with FK506 single therapy or non-treated groups.

Activation markers involved in antigen presentation (MHC II) and immune cells migration and adhesion (ICAM1) where slightly decreased in spleen cells from FTY720 and
FTY720+FK506 treated mice when compared with FK506 alone. However, this decrease was more important in FTY720 treated group. A significant decrease at MHC class I and class II expression was observed in murine peritoneal macrophages stimulated with IFN- $\gamma$ in vitro when FTY720 was added as reported by Hwang et al. ${ }^{29}$ suggesting that FTY720 acts not only in T cells but also in antigen presenting cells (APC). In agreement with Hwang data, our results suggest that besides the decrease in lymphocytes capable to promote rejection, antigen presentation and effector cell migration to the inflammatory site (graft) is prevented or delayed by FTY720. Taking into account that MHC-deficient mice present a delay in skin allograft rejection when compared with wild type animals $^{30}$ it could be argued that FTY720 therapy caused improvement in skin allograft survival in our experiments, among other mechanisms, by preventing MHC II expression in APCs.

Apoptosis levels increased in all treated groups in comparison with Tx non-treated mice but FTY720+FK506 caused the higher apoptosis levels in splenocytes. This finding could explain the decreased number of lymphocytes in spleen and blood obtained in the group treated with FTY720+FK506.

Ten days after transplantation there was a preserved macroscopic view of the skin graft in FTY720+FK506 whereas the Tx non-treated Group had already rejected the graft. However, our findings in skin histology showed that the infiltration score in FTY720+FK506 Group was only slightly lower that in Tx non-treated Group. Infiltrating cells in all groups were mainly lymphocytes and neutrophils. In opposite to our findings some authors have found that FTY720 impairs $\mathrm{T}$ cell infiltration in the allograft. Yanagawa et al. ${ }^{31}$ showed that skin transplant in non-treated MHC-incompatible rat strains causes a higher amount of infiltrating $\mathrm{CD} 8^{+} \mathrm{T}$ cells when compared with $\mathrm{CD}^{+} \mathrm{T}$ cells five days after transplantation. $\mathrm{CD}^{+} \mathrm{T}$ cells infiltration was not prevented by FTY720 but there was a significant decrease of this cell phenotype in comparison with non-treated rats. FTY720 has been shown to have more effects on $\mathrm{CD}^{+} \mathrm{T}$ cells than in $\mathrm{CD} 8^{+} \mathrm{T}$ cells and that the later cell subtype is sufficient to mediate allorecognition and graft rejection even in absence of T cell helper. ${ }^{32}$ Wang et al. ${ }^{33}$ showed that FTY720 cause cardiac allograft rescue from ongoing rejection and was associated with decrease in blood lymphocytes and increase of these cells in peripheral lymph nodes. Mononuclear cells infiltration was not prevented by FTY720 treatment but the presence of these cells was not as high as in non-treated group. Hwang et $a l .{ }^{29}$ showed that in murine cardiac transplantation $10 \mathrm{mg} / \mathrm{kg} /$ day of FTY720 was associated with strong suppression of acute rejection in comparison with CsA (40 mg/kg/day). CsA group presented histological findings such as coronary vasculitis with intraluminal accumulation of mononuclear leukocytes which were attenuated by FTY 720 treatment. It could also be argued that 
our histology findings five days post transplantation were associated with tissue damage rather than with rejection process. Yet, pro-inflammatory cells and their products might be necessary to maintain the graft micro-environment balance which guarantees tissue acceptance or rejection delay.

In conclusion, FTY720 alone or in association with FK506 showed efficacy in delaying skin allograft rejection mainly due to apoptosis causing decrease of lymphocyte numbers in periphery and impairment in the expression of activation markers by these cells. Our results show that FTY720 might be associated to subtherapeutic levels of FK506 causing marked prolongation of skin allograft survival when compared with FK506 monotherapy. The major implications for this finding are the possibility of drugs synergistic combinations, reduced doses of immunosuppressive drugs and in turn less side effects.

\section{Resumo}

O objetivo na área dos transplantes é o desenvolvimento de novas drogas que possam ser associadas a inibidores da calcineurina para evitar o processo de rejeição e causar menos efeitos colaterais. FTY720 é um novo composto sintético que apresenta propriedades imunomoduladoras não completamente elucidadas. Foi relatado que o principal mecanismo de ação do FTY720 é a redução do número de linfócitos periféricos através do redirecionamento dessas células para órgãos linfóides secundários. O alotransplante de pele entre linhagens de camundongos completamente incompativeis quanto ao MHC foi usado para investigar o potencial de FTY720 isolado ou em combinação com um inibidor da calcineurina - FK506 - na prevenção da rejeição. Também foram avaliados o número e fenótipo das células do sistema imune. A administração de FTY720 como monoterapia ou FTY720+FK506 associou-se a uma diminuição do número total de linfócitos no baço e no sangue e aumento dos niveis de apoptose nos esplenócitos. No grupo tratado somente com FTY720, foi observada uma diminuição mais importante da expressão de CD4 e expressão significativamente menor de moléculas de MHC II e ICAM-1. Apesar de a sobrevida do aloenxerto ter sido igual para os grupos tratados com FTY720 ou FTY720 +FK506, a associação das drogas promoveu ausência de necrose macroscópica da pele por um periodo maior do que os outros tratamentos (FTY720, FK506) e os achados histológicos mostraram menor infiltrado celular. Nossos resultados sugerem que uma diminuição do número de células $T$ efetoras devido a elevados níveis de apoptose e o prejuizo da apresentação de antígenos foram os eventos associados à administração de FTY720+FK506. Rev. bras. hematol. hemoter. 2008; 30(3):181-187.

Palavras-chave: Camundongo; alotransplante de pele; rejeição; imunossupressão; citometria de fluxo.

\section{Acknowledgments}

David Andrew Hewitt for the English review, Prof. Dr. José Antonio Cordeiro for statistical analysis.

\section{References}

1. Maki T, Gottschalk R, Ogawa N, Monaco AP. Prevention and cure of autoimmune diabetes in nonobese diabetic mice by continuous administration of FTY720. Transplantation. 2005;79(9):1051-5.

2. Azuma H, Takahara S, Horie S, Muto S, Otsuki Y, Katsuoka Y. Induction of apoptosis in human bladder cancer cells in vitro and in vivo caused by FTY720 treatment. J Urol. 2003;169(6):2372-7.

3. Schmid G., Guba M, Papyan A, Ischenko I, Brückel M. FTY720 inhibits tumor growth and angiogenesis. Transplant Proc. 2005; 37(1):110-1

4. Ueda H, Takahara S, Itoh S, Nomi H, Shibahara N, Katsuoka Y. Preoperative administration of FTY720 prolonged renal allograft survival. Transpl Immunol. 2005;14(1):1-8.

5. Oliveira CM, Borra RC, Franco M, Schor N, Pestana JO, Bueno V. FTY720 impairs necrosis development after ischemia-reperfusion injury. Transplant Proc. 2004;36(4):854-6.

6. Suleiman M, Cury PM, Pestana JO, Burdmann EA, Bueno V. FTY720 prevents renal T-cell infiltration after ischemia/ reperfusion injury. Transplant Proc. 2005;37(1):373-4.

7. Chiba K, Yanagawa Y, Nasubuchi Y, Kataoka H, Kawaguchi T, Ohtsuki M. FTY720, a novel immunosuppressant, induces sequestration of circulating mature lymphocytes by acceleration of lymphocyte homing in rats. I. FTY720 selectively decreases the number of circulating mature lymphocytes by acceleration of lymphocyte homing. J Immunol. 1998;160(10):5037-44.

8. Goetzl EJ, Rosen H. Regulation of immunity by lysosphingolipids and their G protein-coupled receptors. J Clin Invest. 2004;114 (11):1531-7.

9. Hla T. Signaling and biological actions of sphingosine 1-phosphate. Pharmacol Res. 2003;47(5):401-7.

10. Anliker B, Chun J. Lysophospholipid G protein-coupled receptors. J Biol Chem. 2004;279(20):20555-8.

11. Le Stunff H, Milstien S, Spiegel S. Generation and metabolism of bioactive sphingosine-1-phosphate. J Cell Biochem. 2004;92(5): 882-99

12. Olivera A, Rivera J. Sphingolipids and the balancing of immune cell function: lessons from the mast cell. J Immunol. 2005;174 (3):1153-8

13. Graeler M, Goetzl EJ. Activation-regulated expression and chemotactic function of sphingosine 1-phosphate receptors in mouse splenic T cells. FASEB J. 2002;16(14):1874-8.

14. Wang W, Graeler MH, Goetzl EJ. Physiological sphingosine 1phosphate requirement for optimal activity of mouse CD4+ regulatory T Cells. FASEB J. 2004;18(9):1043-5.

15. Goetzl EJ, Kong Y, Mei B. Lysophosphatidic acid and sphingosine 1phosphate protection of $\mathrm{T}$ cells from apoptosis in association with suppression of Bax. J Immunol. 1999;162(4):2049-56.

16. Mandala S, Hajdu R, Bergstrom J, Quackenbush E, Xie J. Alteration of lymphocyte trafficking by sphingosine-1-phosphate receptor agonists. Science. 2002;296(5566):346-9.

17. Sugito K, Koshinaga T, Inoue M, Ikeda T, Hagiwara N, Fukuzawa M. The effect of a novel immunosuppressant, FTY720, in mice without secondary lymphoid organs. Surg Today. 2005;35(8):662-7

18. Morris MA, Gibb DR, Picard F. Transient T cell accumulation in lymph nodes and sustained lymphopenia in mice treated with FTY720. Eur J Immunol. 2005;35(12):3570-80.

19. Yagi H, Kamba R, Chiba K, Soga H, Yaguchi K. Immunosuppressant FTY720 inhibits thymocyte emigration. Eur J Immunol. 2000; 30(5):1435-44.

20. Rosen H, Alfonso C, Surh CD, McHeyzer-Williams MG. Rapid induction of medullary thymocyte phenotypic maturation and 
egress inhibition by nanomolar sphingosine 1-phosphate receptor agonist. Proc Natl Acad Sci USA. 2003;100(19):10907-12.

21. Xie JH, Nomura N, Koprak SL, Quackenbush EJ, Forrest MJ, Rosen H. Sphingosine-1-phosphate receptor agonism impairs the efficiency of the local immune response by altering trafficking of naive and antigen-activated CD4+ T cells. J Immunol. 2003;170 (7):3662-70.

22. Graler MH, Goetzl EJ. The immunosuppressant FTY720 downregulates sphingosine 1-phosphate G-protein-coupled receptors. FASEB J. 2004;18(3):551-3

23. Matloubian M, Lo CG, Cinamon G, Lesneski MJ, Xu Y. Lymphocyte egress from thymus and peripheral lymphoid organs is dependent on S1P receptor 1. Nature. 2004;427(6972):355-60.

24. Silva FR, Silva LB, Cury PM, Burdmann EA, Bueno V. FTY720 in combination with cyclosporine - an analysis of skin allograft survival and renal function. Int Immunopharmacol. 2006;6(13-14):1911-8.

25. Gillot BJ, Jones ND, Hara M, Wood KJ. Visualization of the in vivo generation of donor antigen-specific effector CD8+ T cells during mouse cardiac allograft rejection: in vivo effector $\mathrm{CD} 8+\mathrm{T}$ cell generation during allograft rejection. Transplantation. 2000; 69 (4):639-48.

26. Hanshaw RG, Smith BD. New reagents for phosphatidylserine recognition and detection of apoptosis. Bioorg Med Chem. 2005; 13(17):5035-42.

27. Gallo AP, Silva LB, Franco M, Burdmann EA, Bueno V. Tacrolimus in combination with FTY720 - an analysis of renal and blood parameters. Int Immunopharmacol. 2006;6(13-14):1919-24.

28. Henning G, Ohl L, Junt T, Reiterer P, Brinkmann V, Nakano H et al. CC chemokine receptor 7-dependent and -independent pathways for lymphocyte homing: modulation by FTY720. J Exp Med. 2001;194(12):1875-81.
29. Hwang MW, Matsumori A, Furukawa Y, Ono K, Okada M, Iwasaki A et al. FTY720, a new immunosuppressant, promotes long-term graft survival and inhibits the progression of graft coronary artery disease in a murine model of cardiac transplantation. Circulation. 1999;100(12):1322-9.

30. Grusby MJ, Auchincloss H, Lee R, Johnson RS, Spencer JP, Zulstra $\mathrm{M}$ et al. Mice lacking major histocompatibility complex class I and class II molecules. Proc Natl Acad Sci USA. 1993;90(9):3913-7.

31. Yanagawa Y, Hoshino Y, Chiba K. The significance of timing of FTY720 administration on the immunosuppressive effect to prolong rat skin allograft survival. Int J Immunopharmacol. 2000; 22(8):597-602.

32. Halamay KE, Kirkman RL, Sun L, Yamada A, Fragoso RC, Shimizu $\mathrm{K}$ et al. CD8 $\mathrm{T}$ cells are sufficient to mediate allorecognition and allograft rejection. Cell Immunol. 2002;216(1-2):6-14.

33. Wang MH, Milekhin V, Zhang H, Huang HZ. FTY720, a new immunosuppressant, as rescue therapy in mouse cardiac transplantation. Acta Pharmacol Sin. 2003;24(9):847-52.

Avaliação: Editor e dois revisores externos

Conflito de interesse: não declarado

This study was supported by Fapesp - grant no 04/14727-0, 06/50347-3.

Recebido: 30/05/2007

Aceito: $04 / 07 / 2007$ 